Ulceration may account for half or more of rebleeding episodes in those given sclerotherapy. ${ }^{30}$ Such episodes were often minor and rarely fatal. When the prognosis of a first variceal bleed occurring during prophylactic sclerotherapy is different from that of a first variceal bleed occurring "spontaneously" it may limit the usefulness of this item as an end point in a clinical trial.

The randomised study of 282 men with alcoholic cirrhosis reported by Gregory et al was even less encouraging. ${ }^{2 x}$ By 22 months mortality in the group given sclerotherapy so exceeded that in the control group (29\% against $17 \%$, $\mathrm{p}=0.009$ ) that the trial was stopped. More treated patients also had bleeding episodes ( $22 \%$ against $16 \%, p=0.02)$. The most recent randomised study by Santangelo. et al in 95 patients with large varices again showed no benefit in the group given prophylactic sclerotherapy. ${ }^{29}$ Mortality was a quarter in both treated and control groups at 13 months. Moreover, there was an excess of episodes of early fatal bleeding in the group given sclerotherapy.

All large centres should know their rate of complication for sclerotherapy and the prognosis of their patients with varices that have not bled. Prophylaxis sclerotherapy should be considered only if this prognosis is similar to that of the controls in Witzel's study or if the patients have factors that put them at high risk, such as the variceal appearance of those in Paquet's trial, and only then if they are being managed in a centre with a low complication rate for variceal sclerotherapy. Otherwise prophylactic sclerotherapy offers little benefit, and most patients will be better served by regular review.

\section{W BULLIMORE}

Lecturer

P FOSTER

Department of Medicine,

St James's Hospital,

Leeds LS9 7TF

1 Barsoum MS, Bolous FI, Bil-Rexby AA, Rizk-Allah MA, Ibrahim AS. Tamponade and injection sclerotherapy in the management of bleeding (eesophageal varices. Br 7 Surg 1982:69:76-8.

2 Terblanche J, Bornman PC, Kahn D, et al. Failure of repeated injection sclerotherapy to improve long-term survival after wesophageal variceal bleeding. A tive vear prospective controlled clinical 983:ii:1328-32

3 Kitano S, Kovanagi N, Iso Y, Higashi H, Sugimachi K. Prevention of recurrence of esophageal varices after endoscopic injection sclerotherapy with ethanolamine oleate. Hepatologv 1987; $810-5$

+ Westaby D, Macloougall BRD, Williams R. Improved survival following injection sclerotherapy for esophageal varices: final analysis of a controlled trial. Hepatologr 1985;5:827-30.

5 Sorensen T. Burcharth F. Pedersen MI., Findahl F. Oesophageal stricture and dvsphagia after endescopic sclerotherapy for blecding varices. (jut 1984:25:473-7.

6 Bullimore DW. Bleeding oesophageal varices: referral bias and survival. 7 R Coll Phwicians Lomd 1985:19:189-91.

Williams R, Westaby D. Lindoscopic sclerotherapy for esophageal varices. Dig Dis Sii 1986:31: $108-21 \mathrm{~s}$

8 Smith PM, Jones DB, Rose JDR. Simplified fibre endoscopic sclerotherapy for oesophageal varies. IR Coll Physiciens Liond 1982:16:236-8.

9 Van Heotegem P'h, Rutgerts P. Feverv J. Brockaert L, De Groote J, Vantrappen G. Sclerotherapy of (eseophageal varices after variceal haemorrhage. Endoscops. 1984;16:95-7.

10 Bacon BR, Camara DS. Duffy MC. Severe ulceration and delaved perforation of the esophagus after endescoipic variceal scleresheraps. (iastrointest Endosic 1987:33:311-5.

11 Barsoum MS, Mexro HA, Bolous FI, Ram $\%$ AF, Ri\%k-Allah MA, Mahmoud FI. The complications of injection sclerotherapy of blecding owsophageal varices. Br 7 Surg 1982;69. 79-81.

12 Seidman 1:, Wether AM. Morin CL, at al. Spinal cord paralysis following sclerotherapy for esophageal varices. Hepatologv 1984:4:950-4.

13 Resnick RH, Chalmers TC, Ishihara AM, ct al. A controlled study of the prophylactic portacaval shunt. A tinal report. Ann Intem Med 1969;70:675-88.

I Jackson FC. Perrin EB, Sinith AG, at al. A clinical investigation of the portacaval shunt. II. Survival analysis of the prophylactic operation. Am. . Surg 1968:115:22-42.

15 Conn HQ, Lindenmuth WW, May CJ, Ramsby GR. Prophylactic portacaval anastomosis. A tale of two studies. Medicinc (Baltimore) 1972:51:27-40.

16 Burroughs AK, D'Hevgere F, McIntvre N. Pitfalls in studies of prophylactic therapy for variceal bleceding in cirrhotics. Hepatologn 1986:6:1+07-13.

17 Pugh RNH, Murray-Lyon IM. Dawson JL, Pietroni MC, Williams R. Transection of the cesophages for blecding (e'sophageal varices. Br 7. Surg 1973;60:6+6-9.

18 Wetb LJ, Sherlock S. The actiology, presentation and natural history of extra-hepatic portal

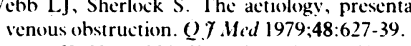

19 Aovama K. Mvers NA. Extra-hepatic pertal hypertension: the significance of variceal hacmorrhage. Iust Pacdiatr. 7 1982:18:17-22.

20 Westaby S, Wilkinson SP, Warren R, Williams R. Spleen size and portal hypertension in cirrhosis. Digestion 1978:17:63-8

21 Dagradi AE, Stempien SI, Owens LK. Bleeding esophogastric varices. Arch Surg 1966:92:944-7.

22 Payuet KJ. Prophylatic endoscopic selerosing treatment of the esophageal wall in varices-a prospective controlled randomized trial. Eindoscopy 1982;14:-5.

Beppu K. Inokuchi K, Kovanogi N, at al. Prediction of variceal hemorrhage by esophageal endoscopv. (iastrointest Endosc 1981:27:213-8.

24 Dagradi $\mathrm{Al}$. The natural history of esophageal varices in patients with alcoholic liver cirrhosis. Im 7 (jastrocuterol 1972:57:520-40.

25 Witzel L, Wolbergs L, Merki H. Prophylactic endoscopic sclerotherapy of oesophageal varices. A prospective controlled studv. Lancet 1985 :i: $773-5$.

26 Burroughs AK. Hamilton G. Prophylactic endescopic variceal sclerotheraps of exsophageal varices. Lancel 1985; i1105-6.

27 Sauerbruch T, Wotza R, Kopcke W, at al. Endoscopic sclerotherapy ST T for prophylaxis of first variceal bleeding in liter cirrhosis. Early results of a prospective randomized trial. (Gustrocnterolege' 1986;90:1765

28 (iregory P. Hartigan P, Amodeo D, at al. Prophylactic sclerotherapy for esophageal varices in alcoholic liver discase: results of a VA co-operative randomized trial. (jastroenterologe 1987;92: $1+14$

29 Santangelo WC, Dueno MI, Lstes BL, Krejs GJ. Prophwlactic sclerotherapv of large esophageal varices. N Engl F Afed 1988:318:814-8

30 Westaby D, Melia W, Hegarty W', Gimson AES, Stellon AJ, Williams R. Use of propranolol to reduce the rebleding rate during injection selerotherapy prior 10 variceal obliteration. Hepulologr 1986;6:673-5.

\title{
The new public health
}

\section{Implementation of the Acheson report is an opportunity for a radically new public health}

Even in their worst moments during the implementation of general management in the NHS community physicians clung to the certainty that if they were abolished they would have to be reinvented. Witness, for instance, the increasing need for vigilance against communicable diseases illustrated by the recent rise in the incidence of human immunodeficiency virus, legionella, measles, salmonella, and listeria infections. ${ }^{1}$ Moreover, no health service can sensibly operate without disease prevention and health promotion and without analysing needs and evaluating outcome. So it is welcome, if unsurprising, that the recommendations of the Acheson inquiry, Public Health in England, ${ }^{2}$ are to be implemented ( $\mathrm{p}$ 378). Many community physicians, particularly those in communicable disease control, health promotion, and planning, will find the implementation of Acheson an opportunity to show what could have been achieved all along given the right backing, but the new directors of public health now have a chance to develop a new and radically different practice of public health.
Independent advocacy, though a popular concept among community physicians, was dismissed by the Acheson inquiry. In fact, public health physicians still can and should shout their case loudly and publicly, ${ }^{3}$ especially with the help of their new annual reports. But they would rarely achieve the policy changes they advocate if they were limited to heckling from the sidelines without being responsible or accountable for the result. Those who want that kind of freedom have misunderstood the nature of power in the health service and would lose public health the great potential which it now has.

On the other hand, if the implementation of the Acheson report were to represent a takeover bid by overweening community physicians resorting to the autocratic habits of many old medical officers of health, it would be doomed to well deserved failure. A vast array of professionals and others outside as well as within the health services are concerned with public health, and real leadership should mean ensuring that all these people work towards understood and shared goals. Power and skill need to be devolved to others so that 
they perform at their best while everything is held together as they do so. Such leadership relies on the power that comes from garnering information (with the ears as well as the computer terminal) and using it to analyse and persuade. It relies on understanding and influencing those who wield executive, political, or professional power, working alongside them, recognising or renegotiating their domains, and breaking down barriers of mutual suspicion. It will rely too on keeping a clear vision of what remains to be achieved. ${ }^{+6}$

Many have doubted whether there will be sufficient resources to implement the Acheson report or enough trained staff to fill the new posts of district controllers of communicable diseases. It would be a foolish repeat of past mistakes to expect the new directors of public health to deliver the goods without having the means to produce them. The task of reviewing training in the basic sciences of public health is already beginning. Few, however, have recognised how much the skills of leadership will be fundamental to applying those sciences. Such skills are rare and will not magically appear. They must be developed, learnt, and constantly improved on, and training programmes need to be designed imaginatively.
In short, public health is too important for its practitioners to succumb to the old syndrome of chronic identity crises compounded by organisational impotence. ${ }^{*}$ The people's health is-or should be-the concern of a wide and mixed range of people and organisations. Those now charged with the role of coordinating these groups have a huge job to do, and public health physicians face a change as radical as that which surgeons underwent a century ago. We must meet that challenge by developing new and appropriate skills, not by reinventing the old public health.

Senior Registrar in Community Medicine,

Parkside Health Authority,

London W2 INY

Cunningham D. Public health in London. Br.Med 7 1988:297:65

2 Committec of Inyuiry Into the Future Develonment of the Public Health Function. Public health in Eingland. London: HMSO, 1988. Acheson report

Ruc R. Advising a health authority. The Community P' Pvicion 1987:2:3.

t Harvev-Jones J. Making it happen: reflections on leadership. London: Collins, 1988.

Turrill EA. Change and innovation: a challenge for the NHS. London: IHSM. 1986.

6 Kotter JP, Lawrence JP. Mavors in action. Five studies in urgan gocemance. New York: John Wilev, Kotter

7 Binstead D. Decelopments in interpersonal skills training. London: Gower, 1986.

8 Lewis J. What price community medicine? The philosophy, practice and politcs of public health since 1919. Brighton: Wheatsheaf Books, 1986

\section{What went wrong at Exeter?}

\section{Many patients overexposed to radiation but only a few at serious risk}

The recent news that 153 patients with cancer had been given doses of radiation $25 \%$ greater than intended has shocked departments of radiotherapy and oncology across the country. This is the worst radiotherapy dosimetric error ever experienced in the United Kingdom. On the face of it, it seems to have been due to simple miscalculation of dose output by a medical physicist after the installation of a new radioactive cobalt source, a standard procedure carried out every three to four years in all departments using telecobalt equipment.'

The new source, which did not come directly from Amersham International (the usual supplier) because it had previously been used in another centre, arrived in Exeter in February of this year. The dose excess seems to have been due to a mistake in measuring the time over which the reference dose was calculated. The physicist may have multiplied by the wrong factor to achieve an equivalent exposure for one full minute. Tragically, this inaccuracy was not then recognised, possibly because the physicist was working on his own and his figures may not have been checked. Although there are no mandatory guidelines relating to checking, the initial calibration of a new highly active cobalt source is the most fundamental dose calibration during the life of that part of the equipment, and subsequent calibration exercises would be based on this figure, making additional inaccuracies more difficult to recognise later on.

What safeguards would normally apply after the installation of a new cobalt source? The most important is that the suppliers also include a test certificate, normally sent with the new source itself, which should be returned after installation and calibration with the physicist's calculation of the dose, usually in roentgen/min at 1 metre $(\mathrm{Rmm})$. Perhaps this would be better if done "blind," but Amersham would normally send its expected figure on the certificate, and in our experience at University College Hospital over the past six source changes our own recording of the absorbed dose in $\mathrm{Rmm}$ has invariably been within $2 \%$ of the expected level. Was this normal procedure carried out at Exeter?
A further uncertainty surrounds the question of how the error was finally noticed. Despite press reports that the vigilance of nursing and radiographic staff led to unexpected skin reactions arousing suspicion, it seems equally possible that the five month period of overexposure (February to July) was brought to an end by chance. A radiation "phantom" apparatus, designed to test absorbed radiation dose within biologically equivalent tissues, was being used in a multicentre comparison of dosimetric consistency, organised by the Institute of Physical Sciences in Medicine. The phantom reached Exeter in July, and unexpectedly high readings gave the game away. Ironically, despite a request by the institute to the Department of Health and Social Security for funding for this project, the department decided that it was not sufficiently important or likely to prove of practical benefit. It would be very disturbing if neither the doctors, the nurses, nor the radiographers concerned picked up a consistent excess in the radiation dose of $25 \%$ over several months, and many radiotherapists would agree that an excess of $15 \%$ or so would normally be clinically detectable. Before we reach a hasty conclusion it is well to remember that the department of radiotherapy and oncology at the Royal Devon and Exeter Hospital has a high reputation for excellence and has, indeed, pioneered the use of new radiotherapy techniques now finding general application. Its throughput is substantial, over 1700 new cases a year, spread among three consultants, who themselves see patients throughout the whole of Devon and are therefore necessarily off site for part of the working day. Effectively there are no junior staff experienced in radiotherapy. Similarly, the department of radiation physics is also overstretched and split between two sites. By the standards of our European or North American colleagues, all British departments of radiotherapy and oncology are understaffed, and most radiotherapists in the United Kingdom see more patients each year than is recommended by the Royal College of Radiologists.

In practice, all radiotherapists know that their own 